\title{
Ethno-Religious Conflicts and the Restructuring of Nigeria Debate: Issues, Trends and Perspectives
}

\author{
Victor Ifeanyi Ede ${ }^{1}$ and Ozioma Faith Chiaghanam,"* \\ ${ }^{1}$ School of General Studies, Michael Okpara University of Agriculture \\ Umudike, Abia State Nigeria \\ ${ }^{2} \mathrm{Ph} . \mathrm{D}$ Candidate, Department of Religion and Cultural Studies, University of Nigeria \\ Nsukka, Nigeria \\ *Corresponding author's email: ozioma.chiaghanam [AT] gmail.com
}

\begin{abstract}
One of the burning national issues in Nigeria in recent times is the issue of political restructuring. Nigeria's ethnic and religious diversities have always influenced political decisions since the amalgamation in 1914. Several administrations, both colonial and post-independence, have fashioned out different political structures for the country. Currently, Nigeria operates a unique federal system in which the federal government wields enormous powers while the federating units are mere subordinates. In recent times, there has been clamour from different quarters for the political restructuring of the country. This paper examined the restructuring debate in the light of the country's ethnic and religious diversities which have given rise to ethno-religious conflicts which have led to loss of lives and destruction of property in recent times. Political restructuring in the context of this study is the decentralization of political power in the country to ensure political balance among various ethnic and religious groups. Findings show that the fundamental issues that gave rise to the call for restructuring include ethnic diversity, religious pluralism and marginalization in the political equation of the country. These have fuelled ethno-religious conflicts which have ravaged most parts of the country. The paper recommends among others a form of political structure in which the federating units should be given the powers to manage their affairs in line with their ethnic and religious affiliations. It is believed that this will reduce the level of ethno-religious conflicts in the country.
\end{abstract}

Keywords---- Conflict, Ethnicity, Politics, Religion, and Restructuring

\section{INTRODUCTION}

The political entity called Nigeria came into being through amalgamation process. The amalgamation process which was concluded in 1914 by Sir Fredrick Lord Luggard brought together the then Northern and Southern protectorates together under a single administration. According to Ademoyega (1981) cited by Ngele (2008) prior to the 1914 amalgamation, the political entity called Nigeria today was administered in separate smaller units: the Northern Nigeria, the Colony of Lagos and the Southern Nigeria. This was corroborated by Farayibi (2017). According to him;

Nigeria was born after the amalgamation of the Southern and Northern protectorates in 1914 by Lord Luggard.

This act brought together independent tribal groups and kingdoms with unique characteristics such as languages, cultural beliefs, political and social structures, forms of government etc under a country called Nigeria (p. 2).

The amalgamation gave the colonialists the leverage to administer the whole country as a single entity.

Several administrations, both colonial and post-independence, fashioned out different political structures for the country. Arthur Richard's constitution of 1946 brought regionalism by dividing the country into three regions. This was followed by the Macpherson Constitution of 1951 which made Nigeria a quasi-federal state. Nigeria became a Federal State following the coming on board of the Lyttleton Constitution of 1954 (Abah \& Nwokwu, 2017). In the 1963 Republican Constitution, Nigeria adopted the regional structure in which the Northern, Eastern and Western regions were given some level of autonomy. According to Farayibi (2017) the 1963 Republic Constitution allowed the three regions coexist as independent subunits with their own resources while the centre played the supervisory role and protecting the territorial integrity of the country.

However, military administrations which started from 1966 introduced unitary system of government in which enormous power was left in the hands of the central government. Akindele (2003) observed that;

There is absolutely no doubt that the pseudo-federal system presided over by General Yakuba Gowon (19661975), Murtala Mohammed and Olusegun Obasanjo (1975-79) severely compromised the integrity of Nigerian federalism, in addition to making a mockery of it, while the regimes of General Muhammadu Buhari (1983-85), Ibrahim Babangida (1985-93) and Sani Abacha (1993-98) slaughtered and buried federalism in the praetorian graveyard of imposed, centralized and authoritarian dictatorship that followed the Shehu Shagari administration of 1979-83. 
The current democratic rule which started in 1999 is an offshoot of the highly centralized structure with the Federal government at the centre wielding more power than the 36 states federating units of the country. As a result of the inability of the current political structure of the country to address the needs of the different ethnic groups that make up the country, there have been frequent calls for the restructuring of the country.

Previously, the clamour for the political restructuring of Nigeria was exclusively done by some pro-democracy groups like the National Democratic Coalition (NADECO), the Pro-National Conference Organization (PRONACO) and the Patriots. However, in recent times, the restructuring debate in Nigeria has dominated national discourse. The tempo and frequency are increasing by the day, especially as the political activities in the build up to the 2019 general elections gain momentum. Both political and religious leaders, the academia, civil societies, and professionals have made several contributions to the issue of restructuring.

\section{CLARIFICATION OF CONCEPTS}

\subsection{Religion:}

Religion as a concept does not have a universally accepted definition. It is defined in many ways and the definitions vary among scholars. Hence Agha (2012, p. 31) noted that "the definition of religion poses some difficulties to every scholar including sages and students, who attempt to define it". Attempts have been made to define religion in different ways. Pearsall (2001) defined religion as the belief in and worship of a superhuman controlling power, especially a personal God or gods. In the same vein, Agha (2012, p. 21) asserted that "religion is the conscious or unconscious belief in spiritual being and elements (forces of nature) with powers". According to Adeniyi (1993), religion is a body of truths, laws and rites by which man is subordinated to the transcendent being. Religion in the context of this paper is a particular system of faith and worship, particularly Christianity, Islam and Indigenous worship systems. Religion is an indispensable aspect of every human society. It helps in moulding the individual and communal lives of the society. Religious inclinations cannot be overlooked in the governance of every society. Religion shapes all the systems in the society including the political systems.

\subsection{Ethnicity:}

Ethnicity as a concept is an immensely complex phenomenon that portrays different perceptions. According to Osaghae (1992), ethnicity refers to a social formation resting upon culturally specific practices and a unique set of symbols and cosmology. Okwudiba (1980) defined ethnicity as a phenomenon associated with interactions among members of different ethnic groups. Ethnic group according to him is a social formation distinguished by the communal character of their boundaries.

\subsection{Political Restructuring:}

Restructuring, according to Bello (2017), is the process of increasing or decreasing the number of components parts that make up a system and re-defining the inter-relationship between them in such a way that the entire system performs more efficiently. Restructuring in the context of a nation requires redefining the relationship between the people and the government, including taking another look at the structures and systems of governance as encapsulated in the constitution (Dimeji, 2017). One of the dimensions of restructuring is political restructuring. Amadi et al., (2017) see political restructuring as;

All forms of adjustments, alterations and cosmetic manipulations aimed at changing the formula on the basis of

which economic resources and political power are shared or distributed among the Nigerian elite (p. 4).

Political restructuring in Nigeria also implies divesting the central government of certain powers it wields and limiting its influence in such areas as fiscal policies, military defence, foreign policy, immigration and national elections (Nwankwo cited by Nuhu, 2016). Political restructuring in the context of this study is the decentralization of political power in the country to ensure political balance among the ethnic and religious groups. It is intended to lay an institutional foundation for a more just and equitable sharing of the political space by the country's multi ethno religious groups.

\section{FUNDAMENTAL ISSUES IN THE RESTRUCTURING OF NIGERIA DEBATE}

Several issues have led to the renewed call for the political restructuring of Nigeria. Among the issues are marginalization, non-adherence to the federal character principle, ethnic diversity and religious pluralism in Nigeria.

\subsection{Marginalization and non-adherence to the federal character principle:}

There have been complaints of marginalization by different groups and segments of the country in the political equation of the country in recent time. People complain of marginalization in the area of appointment into key position in the country. There is also marginalization in the area of distribution of revenues accrued to the government as well as allocation of developmental projects. There have been bias, favouritism, nepotism and tribalism in the nation. People who are in positions of authority tend to favour their ethnic and religious groups to the disadvantage of others. Marginalization is as a result of non-compliance to the federal character principle which is enshrined in the country's constitution. The principle of federal character stipulates that there should be equity in the distribution of the national wealth and appointments.

The non-adherence to the federal character principle has become more pronounced in the current Buhari led administration. Abah and Nwokwu (2017) captured the situation thus; 
The age long rape on the federalist principles coupled with the apparent abuse of federal character principle enshrined in the Nigerian constitution by the Buhari led administration in the areas of appointment into key positions and alleged marginalization and neglect of some sections of the country may have awaken the consciousness of Nigerians on the need for urgent restructuring of the Nigerian Federation (p. 1519).

There is no gainsaying the fact that such observable imperfections in the country's policy have triggered protests, agitations and patriotic calls for restructuring of the Nigerian political structure.

\subsection{Ethnic Diversity}

Nigeria as a country is composed of diverse ethnic nationalities. Echiegu (2014) argued that Nigeria has well over 250 ethnic nationalities with three main ethnic groups (Hausa/Fulani, Igbo and Yoruba). The heterogeneous character of ethnic nationalities in the country gave impetus for adoption of federalism in Nigeria by colonialist. Federalism as a system of government is believed to encourage unity in diversities as it allows the constituent units some level of autonomy to manage their own local affairs in areas of their jurisdictions (Abah \& Nwokwu, 2017). The tearing force of ethnic diversity in any society makes it imperative for every plural society to operate a structure that can give all the nationalities a sense of belonging thereby promoting unity in diversities. Amadi et al., (2017) observed that "the combined forces of ethnic pluralism and cultural diversity in any political society make political restructuring imperative so as to maintain unity in diversity in the system" (p. 1).

\subsection{Religious Pluralism}

Nigeria's diversity is not only in ethnic nationalities but also in religious affiliations. Nigeria has adherents of several religions with Christianity, Islam and African Traditional Religion as the dominant religions. The ethnic and religious dimensions in Nigeria have been closely related such that different ethnic groups are associated with different religions. The Hausa/Fulani ethnic group are associated with Islam; the Igbo of Southern Nigeria are predominantly Christians while the Yoruba are partly Christians and partly Muslims. However, the African Traditional Religion has been the indigenous religion of the people before the advent of the foreign religions of Islam and Christianity. This religious plurality has been the root cause of majority of the conflicts witnessed in the country, hence the need to give religion a considerable place in the restructuring of the country.

\section{PERSPECTIVES IN THE RESTRUCTURING NIGERIA DEBATE}

There are various perspectives in the restructuring debate in Nigeria. As laudable as the call for restructuring sounds, there is a wide disagreement over the real meaning of restructuring or what exactly needs to be restructured. While some people are in favour others are against the restructuring of the country. Thus, there exist the protagonists' views and the antagonists' views in the restructuring debate.

Those who oppose restructuring argue that those who call for restructuring in Nigeria today are doing so with some kind of hate in their minds against the North. For them, the proponents of restructuring are trying to find a way of denying states from the North the opportunity of getting the kind of shares they are receiving from the federation account (Yakassai, 2016). Sani cited by Nuhu (2016) asserted that the North is opposed to restructuring of Nigeria because there is nothing to restructure. He argued that those who call for political restructuring that would enable constituent units of the country to develop at its own pace are unwittingly advocating that Nigerians should live as if they are in different countries, where some citizens would live in a comfort zone, while others would live on the fringe.

The proponents of restructuring on the other hand argue that the current political structure of the country should be changed. The current political structure of the country can no longer serve the purpose of encouraging unity in diversity in Nigeria (Abah \& Nwokwu, 2017). Meanwhile, there are different ideas of the form and shape restructuring should take, ranging from devolution of power, resource control and regional autonomy to creation of more states.

The high concentration of powers and resources at the centre (federal government) has reduced the federating units to the level of being subordinates that are incapable of carrying out certain important functions. The federal government currently retains the largest portion of the country's revenues and has the overriding rights to own all mineral resources found in any part of the country. These have led to the call for devolution of more powers and resources to the federating units. According to Abah and Nwokwu (2017);

The kind of restructuring that can reduce to barest minimum the high level of agitations and protests in the country is that which is based on devolution of more powers and resources to the constituent states (p. 1524).

Some other advocates are motivated by the need to give geographical expression to ethnic identities, and therefore call for creation of more states. This will balance the number of states in all the geographical zones of the country. Those who call for regional autonomy base their stand on the fact that majority of the current 36 states are not viable. They therefore make a case for the integration of states along geographical zone lines to create economies of scale (Dimeji, 2017). Okorocha (2017) cited by Paul et al (2017) captured the different views thus;

Every geographical zone has its own interpretation of restructuring. To the South-East, restructuring means creation of an additional state. For the South-South, restructuring means resource control. For the South-West, it means devolution of power and the North may see it as differently, but whatever is the case, we are better off as a united Nigeria (p. 17). 
These positions should be reconciled in order to forge ahead. It is the position of this paper that restructuring is the way to go in order to accommodate the religious and ethnic diversities of the country.

\section{ETHNO-RELIGIOUS CONFLICTS AND THE NEED FOR RESTRUCTURING NIGERIA}

Ethno-religious conflict according to Salawu (2010) means a situation in which the relationship between members of one ethnic or religious group and another of such group in a multi-ethnic and multi-religious society is characterized by lack of cordiality, mutual suspicion and fear, and a tendency towards violent confrontation. In a multi-ethnic and multi-religious country such as Nigeria, there is usually high level of mutual suspicions and fears as a result of the tendency towards violent confrontations by members of the different ethnic and religious groups. According to Idike and Eme (2015);

Nigeria is undoubtedly one very tense country, insofar as ethno-religious relationships are concerned. A combination of interrelated crises has stretched the bonds of unity, the fabrics of nationhood, as well as the ingredients of citizenship identity, very thin, to a potentially snapping point (p. 76).

Since the attainment of independence in 1960, many parts of Nigeria have witnessed conflicts related to ethnic and religious differences. Notable among ethno-religious conflicts in Nigeria according to Fawole and Bello (2011) are the Maitatsine religious disturbances in parts of Kano and Maiduguri in the early 1980s, Jimeta Yola crisis religious disturbance (1984), 2 ango Katof crisis in Kaduna State (1992), Bulumkutu Christian-Muslim riots (1982) and Kaduna polytechnic muslimchristian skirmishes (1981-1982).

Prominent among the ethno-religious crises that took place in the country was the Sharia crisis. On February 11, 2000 the Islamic Sharia legal system was introduced in Zamfara state. Afterwards there was its subsequent introduction in eleven other States of Northern Nigeria, including Katsina, Kano, Sokoto, Bauchi, Niger, Gombe, Jigawa, Borno, Kebbi, Yobe and Kaduna States (Ede, 2017). In each case, the introduction of the Sharia law was accompanied by controversies which led to series of crises that claimed so many lives and displacement of people.

In the case of Kaduna which is populated perhaps equally by Christians and Muslims, the tension degenerated to very violent conflicts in February and May 2000, that saw to the death of thousands of Muslims and Christians, including a Catholic priest and a legislator (Ehusani, 2002, p. 1).

The riots left at least 3,000 persons dead and led to the displacement of over 63,000 people within Kaduna and its surroundings (International Displacement Monitoring Centre, 2007). These displaced persons sought refuge in the police and army barracks, considered to be the safest places in the heat of the conflicts. Although Sharia legal system is an agelong practice among the Muslim population in the state, what triggered the Sharia conflicts of 2000 was the impression of the Christian citizens that the action will turn Kaduna State into a Muslim state (Alao \& Mavalla, 2016). Between February 2000 and March 2002, similar Sharia-related riots erupted in parts of Kaduna, Bauchi, Plateau, Niger and Nasarawa States. The tension generated by the Sharia all over the country was such that a quarrel between two people of different faiths (Muslim and Christian) often degenerated to inter-ethnic and inter-religious conflict in which hundreds of lives were lost and property worth millions of Naira were destroyed, while survivors relocated to safer places.

The emergence and activities of the dreaded Islamic sect popularly known as Boko Haram in the Northern Nigeria have been issues of concern to the security of the country. The group was founded by Mohammed Yusuf in Maiduguri, the capital of Borno state. Yusuf had a strict, fundamentalist interpretation of the Qur'an and believed that the creation of Nigeria by British colonialists had imposed a Western and un-Islamic way of life on Muslims. He established a religious complex which included a mosque and an Islamic school which attracted poor Muslim families from across Nigeria and neighbouring countries. The centre had the political goal of creating an Islamic state, and became a recruiting ground for jihadists (Ede, 2017).

At the early stage, the group was not violent as Yusuf did not openly preach violence (Kukah, 2015). However, following the attack on the group by the Nigerian security forces in 2009 and the subsequent killing of Mohammed Yusuf, the group turned violent and started unleashing mayhem through bombing of government and religious institutions. Banjo (2016) aptly captured the incidents that led to the violent activities of the Boko Haram group thus:

Authorities from a task force known as Operation Flush II in Maiduguri confronted Yusuf's followers in 2009, wounding at least 17 Boko Haram members. Yusuf angrily denounced the security forces and called on his followers to rise up against them. In a violent campaign that stretched some five days they attacked police stations and engaged in gun battles before the military brutally cracked down. Yusuf was eventually captured by soldiers and then handed over to police, who shot him dead. Police claimed he tried to escape when they killed him, but witnesses said he was executed. His body was shown on state television and the security forces declared Boko Haram finished (p. 2).

Boko Haram re-emerged in 2010 with assassinations and a major raid on a prison more than a year going underground. Yusuf's deputy, Abubakar Shekau, who police claimed had been killed in the 2009 uprising, began to appear in videos as the group's new leader. Attacks gradually grew more deadly and sophisticated, particularly with the use of explosives.

Another aspect of ethno-religious violence that has claimed so many lives in Nigeria in recent times is the activities of Fulani Militia. Inter-communal violence caused by competition between local farming communities and nomadic herdsmen has plagued Nigeria's Middle Belt (Benue, Kaduna, Plateau, Nasarawa and Taraba states) for many years and is spreading to other states (Oladeji,2015). Clashes between local farmers and the Fulani herdsmen have continued to leave 
a bloody trail, with its attendant destruction of property, farmlands and whole communities. Human Rights Watch (2015) said that more than 1000 people were killed between December 2014 and July 2015, and that in Benue state, more than 100 villages were sacked by suspected Fulani herdsmen in 2012 alone.

In January 2013, Fulani herdsmen attacked some villages in Nasarawa state killing 10 people and displacing over 5,000 people. In a fresh attack of some villages in Nasarawa state about 33 people were killed in November 2014 (Nebie, 2014). More attacks by the armed Fulani herdsmen came in 2016. Duru (2016) reported a gruesome attack on Agatu Local Government Area of Benue state in February 2016 in which about 7,000 people were sacked from six villages by the Fulani herdsmen. Ameh (2016) observed that despite heavy gunshots by the herdsmen, no military or security presence was felt. According to him over 200 persons were killed and houses were razed. In April, 2016 there was a renewed attack on Agatu by the armed herdsmen. Statistics from the Benue state Emergency Management Agency (SEMA) indicated that no fewer than 300 persons died in the renewed violence. According to the statistics, property worth millions of Naira were destroyed while more than 10,000 persons were displaced from the villages in the Local Government Area (Abujah, 2016). In Taraba state, Fulani herdsmen attacked Angai and Ndole villages in Gashak Local Council Area on 11th April, 2016. No fewer than 44 persons were killed while others fled to neighbouring Cameroun Republic and nearby Local Concil Areas (Tsoka, 2016). Uzodinma (2016b) also reported an attack by the Fulani herdsmen in Enugu state in April 2016. The herdsmen attacked Ukpabi Nimbo in Uzo-Uwani Local Government Area on 25th April 2016 killing over 40 people. Survivors fled to neighbouring Communities. Two days after the Ukpabi Nimbo attack, there was another attack by the Fulani herdsmen in Umuchigbo Community in Enugu East Local Government Area of Enugu state (Uzodinma, 2016a). It is very clear that the deadly escapades of arms bearing herdsmen are becoming increasingly unsettling. They have let their footprint in virtually every part of the country. In their latest outings, they have been very unsparing of the communities.

The various ethno-religious conflicts were a critical and potent force for socio-political instability; they portray the gross inadequacy and ineffectiveness of the Nigerian security agencies in securing the lives and property of the citizens. This can be attributed to the highly centralized security system in the country in which the states and local governments have little or no control over the security apparatus. This calls for the political restructuring of the country to allow for state police that can enforce laws peculiar to each federating unit.

\section{RECOMMENDATIONS}

The following recommendations are necessary:

1. In the interim, there should be strict adherence to the principle of federal character in the appointment of people in key positions in public institutions to reflect the heterogeneous character of the country.

2. In restructuring the Nigerian polity, each federating units should be given the power to operate in line with their religious and ethnic affiliations.

3. No religion or ethnic group should be given preferential treatment in the restructuring project. This will help to ensure the promotion of a sense of belonging among the different ethnic and religious groups in the country.

4. There should be devolution of more powers to the federating units with the accompanying resources. This will allow the federating units have greater control of the resources in their areas.

5. Minority ethnic groups should be taken into consideration and be protected at all levels in the restructuring project. This will give them a sense of belonging so that no single individual, ethnic group, geographical segment or social group will feel alienated or unwanted in terms of what he or it can contribute to the nation or in terms of having a fair share of national wealth.

\section{CONCLUSION}

Though the mantra of restructuring has continued to dominate national discourse in Nigeria today, it has become challenging to establish a common meaning that will be acceptable to all. This is as a result of the diversities in religion and ethnicity in the country. Political restructuring has been viewed from diverse perspectives, but the bottom line is the need to ensure a just and egalitarian society for the different religions and ethnic groups in the country. There is no doubt that the current political structure of the country, in which the federal government wields overriding political powers to the disadvantage of the federating units, is not healthy for national development and peaceful coexistence. The country should therefore be restructured in such a way that there will be an equitable distribution of political power and resources among the different federating units. This should be done in line with the religious and ethnic backgrounds of the Nigerian people.

When Nigeria is properly structured politically, the harnessing of the potentials in our religious and ethnic lives to develop the country will be ensured. Restructuring will no doubt make the country more stable politically and bring more economic progress. A properly structured Nigeria will encourage hard work and competition among the federating units, thereby allowing each unit to develop at its own pace.

\section{REFERENCES}

- Abujah, R. (2016). The aftermath of Agatu communal clash with Fulani herdsmen. Retrieved fromwww.beltnaija.com/2016/04/this-mus... on 28/04/2016.

- Ab--ah, E. O. \& Nwokwu, P. M. (2017). Restructuring the Nigerian federalism: The proposed form and shape. Middle-East Journal of Scientific Research 25 (7): 1518-1526.

- Adeniyi, M. O. (1993). 'Religion and politics: An eye bird's view of development in Nigeria', In R. D. 
Abubakar, (ed.) Religion and politics in Nigeria (p. 23) Ilorin: NASR Publications.

- Agha, U. A. (2012). Religion and culture in a permissive society. Enugu: Idika Press.

- Akindele, R. A. (2003). Foreign policy in federal politics: A case study of Nigeria. In A. T. Fana and S. G. Egwu (eds), Federalism in Africa. Abakiliki: Africa World Press Inc.

- Alao, O. E. \& Mavalla, A. G. (2016). Kaduna state sharia crisis of 2000: The lessons and challenges after sixteen years. IOSR Journal of Humanities and Social Science 21, (1): 08-14.

- Amadi, O. S., Echem, M. O., Nwoko, M. C. O. \& Inyikalum, D. (2017) Federalism and political restructuring in Nigeria: Analysis of the rationale and challenges. International Journal for Social Studies 3 (11): 1-15.

- Ameh, C.G. (2016).“300 reportedly killed in renewed Agatu crisis”. Dailypost. Retrieved from www.dailypost.ng/2016/02/26/300-reportedly-killed-...on 28/04/2016.

- Banjo, T. (2016). The history of Boko Haram: Here's all you need to know. Retrieved from http://www.nigerianmonitor.com/the-history-of-boko-haram-heres-all-you-need-to- know/ on 15/06/2017.

- Bello, S. A. (2017). Restructuring Nigeria: A critical analysis. Retrieved from https://www.thisdaylive.com/index.php/2017/06/11/restructuring-nigeria-a-critical- analysis/ on 22/09/218.

- Dimeji, A. (2017) Here is how to restructure Nigeria, cleric breaks it down. Retrieved from https://www.pulse.ng/news/politics/tunde-bakare-here-is-how-to-restructure- nigeria-cleric-breaks-it-downid7403870.html on 22/09/2018.

- Duru, P. (2016).7,000 persons displaced in Fulani herdsmen, Agatu farmers clash in Benue. Retrieved from http://www.vanguardngr.com/2016/02/7000-persons-displaced.... on 29/04/2016.

- Echiegu, A. O. U. (2014). Inter-ethnic vengeance: The bane of enduring peace in multi- ethnic nation state. Abakaliki: Citizens' Advocate Press.

- Ede, V. I. (2017). Christian churches' response to the plights of the internally displaced persons in Nigeria. Unpublished Ph.D Thesis Department of Religion and Cultural Studies, University of Nigeria, Nsuka.

- Ehusani, G. (2002). A brief survey of the sharia crisis in Nigeria. Retrieved from http://www.georgeehusani.org/home/index.php/papers-and- essays/183-a-briefsurvey- of-the-sharia-crisis-innigeria on 20/07/2017.

- Farayibi, A. O. (2017). The Structure of Nigeria's restructuring rhetoric. Ibadan: Centre for Allied Research and Economic Development.

- Fawole, O. A. and Bello, M. L. (2011). The impact of ethno-religious conflict on Nigerian federalism. International NGO Journal 6(10): 211-218.

- Human Rights Watch (2015). Nigeria: At least 1,000 civilians dead since January. Human Rights Watch Daily Brief, 31 July, 2015.

- Idike, A. A. \& Eme, O. I. (2015). Ethno-religious identities in Nigeria: Implications for governance in Nigeria. Journal of Policy and Development Studies 9 (5): 72-87.

- International Displacement Monitoring Centre (2007). Nigeria: Institutional mechanisms fail to address recurrent violence and displacement. Retrieved from www.internal- displacement.org/asset... on 20/04/2016.

- $\quad$ Kukah, M. H. (2015). Nigerians under the menace of Boko Haram: Some random thoughts. Encounter Journal of African Life and Religion, 11: 28-39.

- Nebie, F. (2014). Fulani gunmen attacked Nasarawa villagers, killed 33 farmers. Retrieved from http://naijagist.com/Fulani -gunmen-attack... on 28/04/2016.

- Ngele, O. K. (2008). Religion, politics and ethnicity: Challenges of pluralism in Nigerian development. Bassey Andah Journal 1: 177-190.

- Nuhu, Y. (2016). What is restructuring in the era of change in Nigerian politics. Proceedings of IASTEM International Conference, Dammam, Saudi Arabia, 17th-18th December, 2016.

- Okwudiba, N. (1980). Ethnic politics in Nigeria. Enugu: Fourth Dimension Publishers.

- Oladeji, A. (2015). Humanitarian crises and internally displaced persons: Addressing the plights of youth and women victims in Nigeria. Basic Research Journal of Social and Political Sciences, 3 (3), 42-55.

- Osaghae, E. E. (1992). Ethnicity and democracy, In A. Fasoro et al (eds) Understanding Democracy (p. 51). Ibadan: Book Craft Limited.

- $\quad$ Paul, S. O., Audu, E. \& Eri, K. (2017). Ethnic agitations and restructuring question in Nigeria: The aftermath of 2015 general elections. International Journal of Innovative Social Sciences \& Humanities Research 5(3):14-24.

- Pearsall, J. (ed) (2001). The concise oxford dictionary-tenth edition. Oxford: University Press.

- Salawu B (2010). Ethno-Religious conflict in Nigeria: Causal analysis and proposals for new management strategies. European Journal of Social Sciences 12: 3.

- Tsoka, K. (2016). Scores killed in Taraba, as Fulani herdsmen attack villages. Retrieved from guardian.ng/news/scores-killed-in-taraba-as-... on 28/04/2016.

- Uzodinma, E. (2016a). Schools shut as Fulani herdsmen launch fresh attack in Enugu community. Retrieved from dailypost.ng/2016/04/27/happening-n... on 28/04/2016. 
- Uzodinma, E. (2016b). Scores killed as herdsmen attack Enugu community, residents flee home. Retrieved from dailypost.ng/2016/04/25/scores-kill...on 28/04/2016.

- Yakassai, T. (2016, September, 25). North divide over Nigeria: Arewa leaders sing discordant tunes over restructuring. Sunday Sun, pp. 30-31. 